\title{
RESEARCH PAPER \\ DEVELOPMENT AND PERFORMANCE EVALUATION OF AN ABRASIVE WEAR TESTING EQUIPMENT FOR TILLAGE TOOLS
}

\author{
E. Y. H. Bobobee ${ }^{1}$ and F. Kumi ${ }^{2}$ \\ ${ }^{1}$ Department of Agricultural Engineering, KNUST, Kumasi \\ E-mail: emmanuel.bobobee@gmail.com \\ ${ }^{2}$ Department of Agricultural Engineering, University of Cape Coast, Cape Coast.
}

\begin{abstract}
The wear of tillage tools is a major source of economic constraints to local farmers. Estimating wear in the field is time consuming and expensive. Abrasive wear testing machines developed in advanced countries are not available in Ghana. This makes the study of wear related problems at laboratory levels difficult in the country and most third world research laboratories. The main objective of this study was to develop and evaluate equipment for testing the abrasive wear of tillage tools in the laboratory. The equipment consists of a circular soil bin, support frame, power transmission system and arm-subassemblies. The equipment was evaluated using a caststeel ploughshare in soils from KNUST (Anwomaso Research Farm, 69\% sand), Wenchi (67\% sand), Ho (73\% sand), Mampong (68\% sand) and Akatsi (83\% sand), all in Ghana. The wear experiment was arranged in a completely randomized design with the soils from the five sites as the treatment. Each treatment was replicated five times. The wear rate of soils from Akatsi and Ho showed increasing trend with increasing moisture content while that of Wenchi and Mampong showed a reverse trend up to $13 \%$ and $15 \%$ moisture content, respectively. The soil from Akatsi produced the highest wear of 4.11g. The wear in the soils from Ho, Mampong, Wenchi and KNUST were $3.16 \mathrm{~g}, 2.90 \mathrm{~g}, 2.88 \mathrm{~g}$ and $1.36 \mathrm{~g}$, respectively with the least wear from the KNUST soil. This confirms the long held belief that the wear rate of tillage tools is directly related to the sand content of the soil. The abrasive wear characteristics of the soils showed strong correlation between mass loss and dimensional loss of the ploughshare.
\end{abstract}

Keywords: Abrasive wear, tillage tool, sand fraction, moisture content

\section{INTRODUCTION}

Most agricultural operations are carried out on the field and are subjected to friction and wear of material that have accompanied man since his very beginning (Mehulic et al., 2005). Wear is defined as damage to a solid surface, gener- ally involving progressive loss of material, because of relative motion between that surface and a contacting substance(s) (Gurumoorthy et al., 2007). Wear is generally described as oxidative, single-cycle or repeated-cycle deformation, abrasive, adhesive or erosive (Allen and 
Ball, 1996). Abrasive wear, which is detachment of the material from surfaces in relative motion, caused by sliding of hard particles between the opposing surfaces, is the most important due to its destructive character (Chattopadhyay, 2001). A study conducted by Tugrul and Icoz (2005) found the wear of ploughshare, cultivator and harrows to be 150 $\mathrm{g} / \mathrm{ha}, 135 \mathrm{~g} / \mathrm{ha}$ and $90 \mathrm{~g} / \mathrm{ha}$, respectively. This indicates that among these tillage tools the ploughshare experiences the most abrasive wear in soils. The ploughshare wear not only affects its working life but directly changes its initial shape, which is one of the most important factors influencing ploughing quality (Horvat et al., 2008). Rapid ploughshare wear has been identified as a major constraint facing farmers in Ghana (Bobobee, 1999). The wear rate of all shares is higher in soils with increasing sand fraction. The main factors affecting wear rate include chemical composition, hardness, and soil physical factors, with sand content and share hardness being the most dominant (Bobobee et al., 2007).

Agriculture still remains the backbone of Ghana's economy. The sector employs $56 \%$ of the population and contributes $28-33.7 \%$ of the national Gross Domestic Product (GDP) (MoFA, 2011). Thus any factor which leads to inefficiency in this sector will have a serious influence on the economic well-being of the country. According to Bahyan (2006), farmers and equipment operators often complain about the high wear rate of tillage tools, which result in high downtime and replacement costs. The economy of Turkey loses 4.4 million dollars annually due to wear of tillage tools (Bayhan, 2006). Other researchers indicate that Canada's economy also loses 3.9 billion dollars annually (Yu and Bhole, 1990), while South Africa and Australia are estimated to lose several millions of dollars due to the wear of tillage tools (Ferguson et al., 1998; Quirke et al., 1988).

In determining the wear of the tillage tools, most field wear tests have been found to be expensive and time-consuming (Tylczak et al.,1999). As a result of this, a number of laboratory soil bins have been developed and installed in certain countries (Al-Janobi and Eldin, 1997). These soil bins for basic and applied research are located in research centres and companies that manufacture agricultural equipment. However, it turns out that none of these facilities are found in Ghana. The objective of this study was to develop and evaluate abrasive wear test equipment for ploughshares and other soil-engaging implements and tools. The equipment was evaluated by investigating the wear of a cast-steel ploughshare using soils from five different agricultural production areas of Ghana.

\section{MATERIALS AND METHODS}

Sites

The sites where the soil samples were taken for the experiment and their textural classes are described in Figure 1 and Table 1. Soil samples were taken to a depth of $40 \mathrm{~cm}$ from the ground surface because this is the depth within which normal conventional ploughing operations are carried out. The sites were; KNUST Anwomaso arable farms located at latitude $6^{\circ}$ $41^{\prime} 56.75^{\prime} \mathrm{N}$, longitude $1^{\circ} 31^{\prime} 25.85^{\prime \prime} \mathrm{W}$ and altitude $274 \mathrm{~m}$ above sea level, Mampong located at latitude $7^{\circ} 2^{\prime} 19.84^{\prime \prime} \mathrm{N}$, longitude $1^{\circ}$ 23 '48.60"'W and an altitude of $401 \mathrm{~m}$ above sea level, both in the semi-deciduous forest agroecological zone of the Ashanti Region. Akatsi is located at latitude $6^{\circ} 8{ }^{\prime} 40.50$ ' $\mathrm{N}$, longitude $0^{\circ} 49^{\prime} 22.05$ ' $\mathrm{E}$ and on an altitude of $57 \mathrm{~m}$ above sea level and Ho, which is located at latitude $6^{\circ}$ 36 ' 0 " $\mathrm{N}$, longitude $0^{\circ} 28^{\prime} 0$ " $\mathrm{E}$ and on an altitude of $158 \mathrm{~m}$ in the coastal savannah zone in the Volta Region. Wenchi is located at latitude $7^{\circ} 45^{\prime} 17.82^{\prime} \mathrm{N}$, longitude $2^{\circ} 5^{\prime} 29.31^{\prime \prime} \mathrm{W}$ and on an altitude $278 \mathrm{~m}$ above sea level in the foresttransitional zone of the Brong-Ahafo Region.

\section{Design of the wear equipment}

The objective for designing the equipment was to construct and use it to test the wear of ploughshares in the laboratory. The characteristics of the equipment are to allow the share to move in the soil under controlled conditions. 


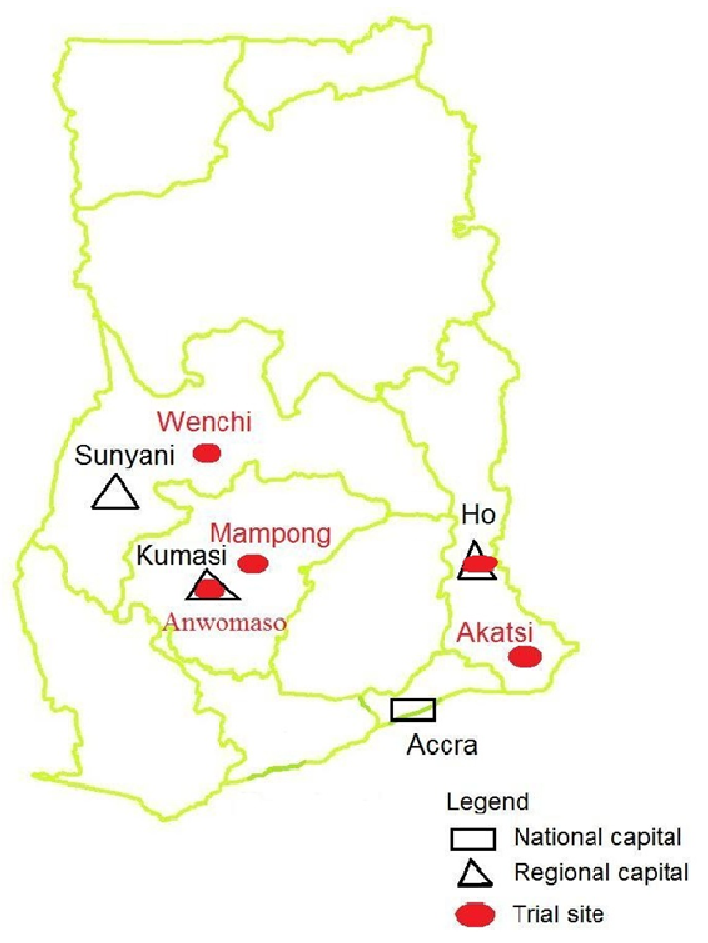

Fig. 1: Sites where soil samples were taken

Table 1: Physical properties of soils under study

\begin{tabular}{llrrrl}
\hline Site & Depth $(\mathbf{c m})$ & \% sand & \% silt & \% clay & Textural class \\
\hline Ho & $0-20$ & 72.81 & 9.38 & 17.81 & Sandy loam \\
& $20-40$ & 70.45 & 12.85 & 16.70 & Sandy loam \\
Akatsi & $0-20$ & 83.02 & 14.98 & 2.00 & Loamy sand \\
& $20-40$ & 81.70 & 14.30 & 4.00 & Loamy sand \\
\multirow{4}{*}{ Mampong } & $0-20$ & 67.33 & 6.95 & 17.81 & Sandy clay loam \\
& $20-40$ & 51.66 & 26.34 & 22.00 & Sandy clay loam \\
\multirow{3}{*}{ Wenchi } & $0-20$ & 66.26 & 6.36 & 27.38 & Sandy clay loam \\
& $20-40$ & 60.40 & 31.60 & 8.00 & Sandy clay loam \\
\multirow{2}{*}{ KNUST } & $0-20$ & 68.92 & 21.06 & 10.02 & Sandy loam \\
& $20-40$ & 57.98 & 19.98 & 22.04 & Sandy clay loam \\
\hline
\end{tabular}

Source: Laboratory analysis of soil samples 
According to Al-Janobi and Eldin (1997), soil bins can be straight or circular depending on the type of study, space, energy requirement and financial constraints. Upon careful considerations, the soil bin was designed to be circular. The equipment operates according to the working principles given by $\mathrm{Yu}$ and Bhole (1990) and Bahyan (2006). The main component of the equipment are; soil bin, roller, sweeper, share holder, a rotating arm and shaft, a standing frame as well as the power transmission system. The design criteria included design for ease of operation. The choice of construction materials for the various parts of the equipment was based on availability, cost and efficiency.

The following equations (Equations 1 - 10) after Khurmi and Gupta, (2003) and Manuwa et al, (2011) were used for the design of the equipment. The belt length selected was calculated from equation (1), below:

$$
\begin{aligned}
& L_{b}=2 C+\frac{\pi}{2}(D+d)+\frac{(D-d)^{2}}{4 C} \\
& \beta=180-60 \frac{(D-d)}{C} \\
& T_{2}=\frac{\mathrm{T}_{1}-\mathrm{mw}^{2}}{\mathrm{~L}_{\mathrm{b}}}+\mathrm{mv}^{2} \\
& \mathbb{B}_{\mathrm{b}}=\left(\mathrm{T}_{1}-\mathrm{T}_{2}\right) \mathrm{Vn}
\end{aligned}
$$

$$
\mathrm{T}_{\mathrm{e}}=\sqrt{\left(\mathrm{K}_{\mathrm{m}}, \mathrm{M}\right)^{2}+\left(\mathrm{K}_{\mathrm{t}}, \mathrm{T}\right)^{2}}
$$

$$
\mathrm{Me}=\left[\frac{1}{2}\left(k_{m} M+\sqrt{\left(K_{m} \cdot M\right)^{2}+\left(K_{t} \cdot T^{2}\right.}\right)\right]
$$

$$
\sqrt{M^{2}+T^{2}}=\frac{\pi r d^{2}}{16}
$$

$\mathrm{P}=\frac{2 \pi \mathrm{NT}}{60}$

$M=\frac{W L}{4}$

$$
\mathrm{D}_{\mathrm{c}}=\frac{\mathrm{F}}{4 \mathrm{~A}}
$$

where,

$\mathrm{L}_{\mathrm{b}}=$ Length of V-belt, mm; C = Centre distance between pulleys $(\mathrm{mm}) ; \mathrm{D}=$ diameter of bigger pulley $(\mathrm{mm}) ; \mathrm{d}=$ diameter of smaller pulley $(\mathrm{mm}) ; \mathrm{T}_{\mathrm{e}}=$ Equivalent twisting moment $(\mathrm{N}-$ $\mathrm{mm}) ; \mathrm{M}_{\mathrm{e}}{ }{ }$ Bending moment of shaft $(\mathrm{N}-\mathrm{mm}) ; \mathrm{T}$ $=$ Torsional moment of shaft $(\mathrm{N}-\mathrm{mm}) ; \tau=$ Yield stress of mild steel $\left(\mathrm{N} / \mathrm{mm}^{2}\right)=215 \mathrm{~N} / \mathrm{mm}^{2 ;} \mathrm{d}_{\mathrm{s}}=$ diameter of shaft $(\mathrm{mm}) ; \mathrm{M}=$ Bending moment $(\mathrm{N}-\mathrm{mm}) ; \mathrm{W}=$ Weight of Shaft $(\mathrm{N}) ; \mathrm{L}=$ Length of shaft $(\mathrm{m}) ; \mathrm{P}=$ Power transmitted by shaft $(\mathrm{W}) ; \mathrm{N}=$ rotational speed of the shaft (rpm); $\mathrm{K}_{\mathrm{m}}=$ Combined shock and fatigue factor for bending; $\mathrm{K}_{\mathrm{t}}=$ Combined shock and fatigue factor for torsion; $\mathrm{D}_{\mathrm{c}}=$ compressive stress on the frame $\left(\mathrm{N} / \mathrm{m}^{2}\right) ; A=$ cross-sectional area of each support leg (angle iron) $\left(\mathrm{m}^{2}\right) ; \beta=$ Arc of belt contact, (degrees); $\mathrm{T}_{1}=$ Tension on tight side of the belt $(\mathrm{N}) ; \mathrm{T}_{2}=$ Tension on slack side $(\mathrm{N}) ; \mathrm{m}=$ mass of belt/length $(\mathrm{kg} / \mathrm{m}) ; \mathrm{V}=$ Belt speed $(\mathrm{m} / \mathrm{s}) ; \mathrm{P}_{\mathrm{b}}=$ Power transmitted by the belt $(\mathrm{kW}) ; \mathrm{n}=$ number of belts; $\mathrm{F}=$ Total force on frame $(\mathrm{N})$.

\section{(4) Construction of the Equipment}

The equipment was constructed at the workshop of the Agricultural Engineering Department, Kwame Nkrumah University of Science and Technology (KNUST) in Kumasi, Ghana. The general manufacturing processes used in the construction of the equipment include marking, cutting, drilling, grinding, turning, milling, welding, rolling, fastening, bending and shaping. The equipment (Figs. 2 and 3) was built in four stages; the bin support frame to serve as a stand, the circular soil bin, arm subassembly and the power transmission system. 
Table 2: Design Specifications

\begin{tabular}{lll}
\hline Design property & Assumed Parameters & Designed Parameters \\
\hline Length of belt & $\mathrm{C}=615, \mathrm{D}=300, \mathrm{~d}=100$ & $\mathrm{~L}_{\mathrm{b}}=1874 \mathrm{~mm}$ \\
Diameter of shaft & $\mathrm{T}=3581 \times 10^{3} \mathrm{~N}-\mathrm{mm}$ \\
& $\mathrm{M}=58920 \mathrm{~N}-\mathrm{mm}$ & \\
& $\mathrm{T}_{\mathrm{e}}=540.372 \times 10^{3} \mathrm{~N}-\mathrm{mm}$ \\
& $\mathrm{M}_{\mathrm{e}}=228.612 \times 10^{3} \mathrm{~N}-\mathrm{mm}$ & \\
& $\mathrm{K}_{\mathrm{m}}=1.5, \mathrm{~K}_{\mathrm{t}}=1.0$ & \\
Roller Pressure & $\mathrm{W}=9.2 \mathrm{~kg}, \mathrm{C}=0.393 \mathrm{~m}$, & $\mathrm{P}=10 \mathrm{kPa}$ \\
Compressive stress on sup- & $\mathrm{A}=0.009 \mathrm{~m}^{2}$ & \\
port frame & $\mathrm{F}=7486.6 \mathrm{~N}, \mathrm{~A}=0.005625 \mathrm{~m}{ }^{2}$ & $\mathrm{D}_{\mathrm{c}}=332.738 \mathrm{kPa}$ \\
Power of Electric Motor & $\mathrm{T}_{1}=825 \mathrm{~N}, \mathrm{~T}_{2}=447 \mathrm{~N}, \mathrm{~V}=7.54 \mathrm{~m} / \mathrm{s}$ & $1440 \mathrm{rpm}, 5.7 \mathrm{~kW}$ \\
Centre Distance of pulleys & $\mathrm{d}=100 \mathrm{~mm}, \mathrm{D}=300 \mathrm{~mm}$ & $\mathrm{C}=615 \mathrm{~mm}$ \\
Tension in Belts & $\beta=173.6^{\circ}, \mathrm{V}=7.54 \mathrm{~ms} \mathrm{~m}^{-1}, \mathrm{~m}=0.27$ & $\mathrm{~T}_{1}=825 \mathrm{~N}, \mathrm{~T}_{2}=447 \mathrm{~N}$ \\
Belt speed & $\mathrm{d}=100 \mathrm{~mm}, \mathrm{D}=300 \mathrm{~mm}$, & $\mathrm{V}=7.54 \mathrm{~ms}^{-1}$ \\
& $\mathrm{~N}=1440 \mathrm{rpm}$ & \\
Arc of contact & $\mathrm{D}=300 \mathrm{~mm}, \mathrm{~d}=100 \mathrm{~mm}, \mathrm{C}=615$ & $\beta=173.6$ \\
Speed ratio & $\mathrm{D}=300 \mathrm{~mm}, \mathrm{~d}=100 \mathrm{~mm}$ & 0.33 \\
Soil volume used & $\mathrm{h}=170 \mathrm{~mm}, \mathrm{r}_{\mathrm{o}}=500 \mathrm{~mm}$ & $\mathrm{~V}=13.352 \times 10^{6} \mathrm{~mm}^{3}$ \\
\hline
\end{tabular}

The support frame was constructed by using angle iron of size $75 \times 75 \times 5 \mathrm{~mm}$. The top frame has a square dimension of $1000 \mathrm{~mm}$ long, 1000 $\mathrm{mm}$ wide and a stand of $700 \mathrm{~mm}$ high. The circular soil bin was formed out of a $3 \mathrm{~mm}$ mild steel plate. The internal diameters of the circular soil bin and the inner cylinder covering the transmission shaft were $1000 \mathrm{~mm}$ and $100 \mathrm{~mm}$, respectively. The arm sub-assembly comprises the main transmission shaft (50mm diameter), the roller and share shafts $(25 \mathrm{~mm}$ diameter each), 900mm arm bar, roller, scraper and the ploughshare. The main transmission shaft was installed in two flange bearings. The ploughshare was fixed unto the share holder by using two bolts, nuts and flat washers. A 3dimensional view of (a) bin support frame (b) circular soil bins (c) the assembly drawing are shown in Fig.2. The assembled equipment as used in the experiment is shown in Fig.3. Three double-groove pulleys were used in the power transmission system. Two of the pulleys were of the same size $(100 \mathrm{~mm})$ and the other was $300 \mathrm{~mm}$ in diameter. V-belts (B type) were used. The experimental set-up of the prototype abrasive wear equipment showing the transmission, the external and internal components are shown in Fig. 3.

\section{Experimental design}

The experimental design used was a completely randomized design with five treatments namely Ho, Akatsi, Mampong, Wenchi and KNUST (Anwomaso) soils. Each treatment was replicated five times with increasing moisture content.

\section{Experimental procedure for wear measure- ment}

The circular soil bin was filled with soil to a 


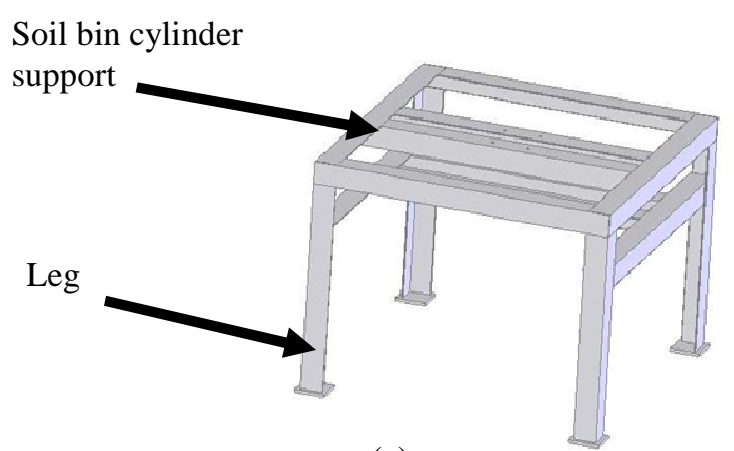

(a)

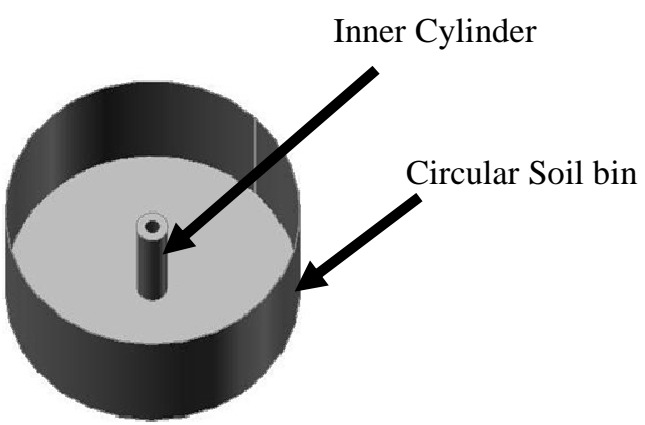

(b)

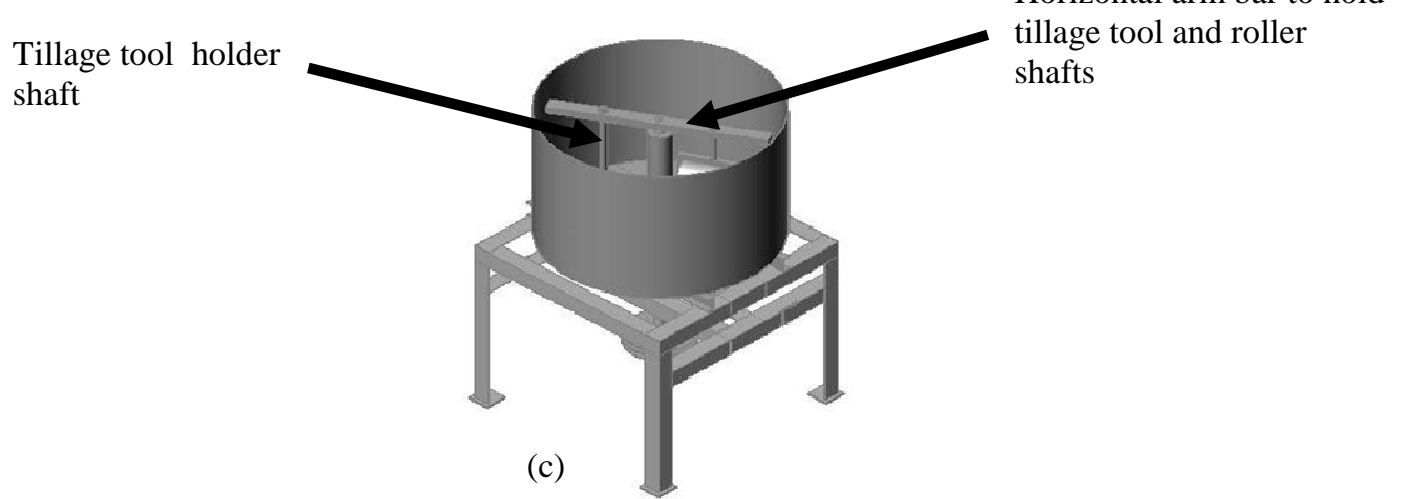

Fig. 2: A 3-dimensional view of the soil bin showing (a) bin support frame, (b) circular soil bin, (c) the assembly drawing

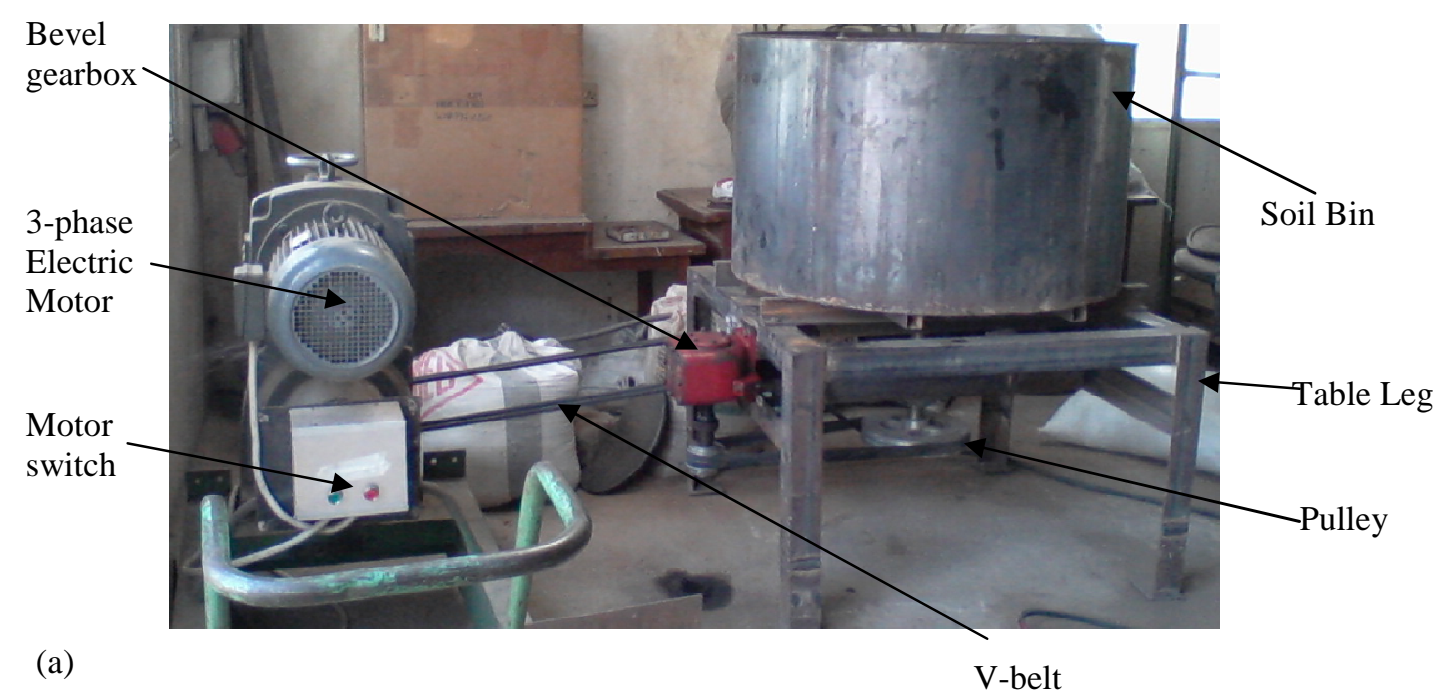

Journal of Science and Technology 다 KNUST April 2013 
Testing the abrasive wear of tillage tools...

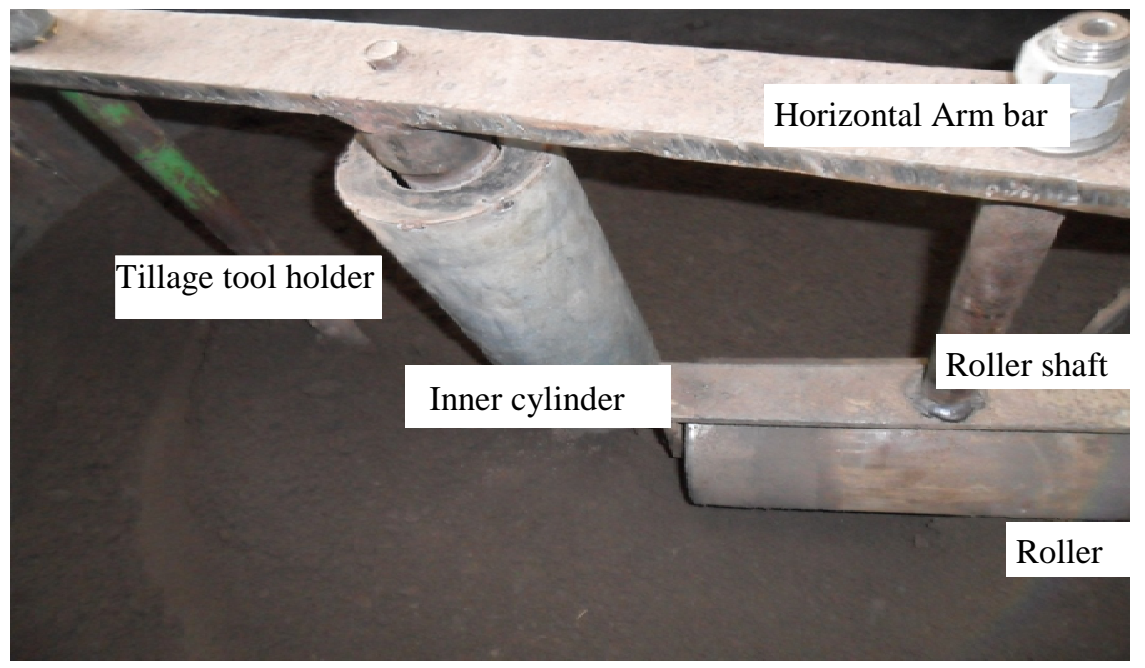

(b)

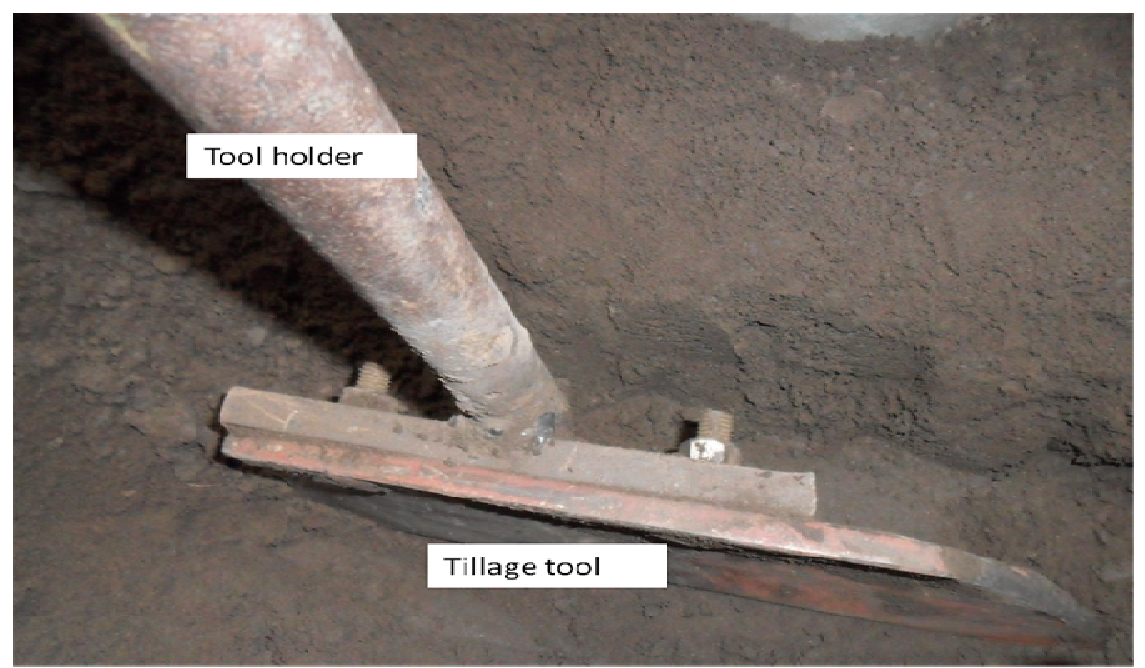

(c)

Fig 3. Experimental set-up of the prototype abrasive wear equipment showing the power transmission, external and internal components (a) soil bin external components, (b) compaction roller inside the soil bin, (c) tillage tool and its holder inside the soil bin

depth of $170 \mathrm{~mm}$. The soil was compacted by passing the roller over it. The ploughshare was cleaned with water, dried and weighed to the nearest gram on a precision electronic balance with an accuracy of $0.01 \mathrm{~g}$. The outline of the ploughshare was drawn on paper and points a,b,c,d,e and $\mathbf{f}$ as shown in Fig. 4, were marked out and measured. The clean, dry ploughshare was fixed unto its holder and set for the equip- ment to operate. The ploughshare moves in an anticlockwise direction in the soil bin. The soil moisture content was measured before each experimental run by taking soil samples from the bin at the ploughshare's working area. The samples were weighed, dried in an oven at $105^{\circ}$ C for 24 hours and weighed again (ASTM, 1991). The ploughshare was washed with water, cleaned and weighed after every one (1) 
hour of constant revolutions to determine the weight loss due to abrasive wear. The share was attached to its holder and the process repeated for five hours a day at the same moisture content. At the end of each day, the soil in the bin was covered with black polythene to reduce evaporation. Each experiment was repeated three (3) times. After completing each experiment, the differences in dimension at the six points a,b,c,d,e,f of the ploughshare were measured to record dimensional losses. The ploughshare was operated at a depth of $100 \mathrm{~mm}$. The average speed of operation was $3.3 \mathrm{~km} / \mathrm{h}$ (40 rpm).

The chemical composition of the cast steel ploughshare after Bobobee et al (2007) is shown in Table 3. The average nominal mass of the ploughshare was $2370 \mathrm{~g}$ with dimension of $350 \mathrm{~mm}$ wide, $100 \mathrm{~mm}$ high and $12 \mathrm{~mm}$ thick.

\section{Data Analysis}

Data collected were subjected to analysis of variance (ANOVA) using MINITAB Statistical
Software Release 15 (Minitab Statistical Package, 2007). Treatment means were separated using least significant difference (LSD) comparison at $\mathrm{p}<0.05$.

\section{RESULTS AND DISCUSSION \\ Comparison of ploughshare wear in various soils}

Fig. 5 shows the effect of sand content on the weight loss of the ploughshare in soils from five sites. Generally, weight loss decreases with decreasing sand contents in the soils. The average weight loss of the ploughshare in the Akatsi soil was $4.11 \mathrm{~g}$, that of Ho soil was $3.16 \mathrm{~g}$, the Mampong soil was $2.90 \mathrm{~g}$, the Wenchi soil was $2.88 \mathrm{~g}$ and the KNUST soil was $1.36 \mathrm{~g}$. This shows that the Akatsi soil had the greatest wear followed by Ho, Mampong, Wenchi, with KNUST recording the least wear. From the texural analysis of the soils within the depths of $0-20 \mathrm{~cm}$ and $20-40 \mathrm{~cm}$, the Akatsi soil had the greatest sand content $(80-83.02 \%)$ followed by Ho (70.45-72.81\%), Mampong (61.66$67.33 \%)$, Wenchi (60.40-66.26\%) and KNUST

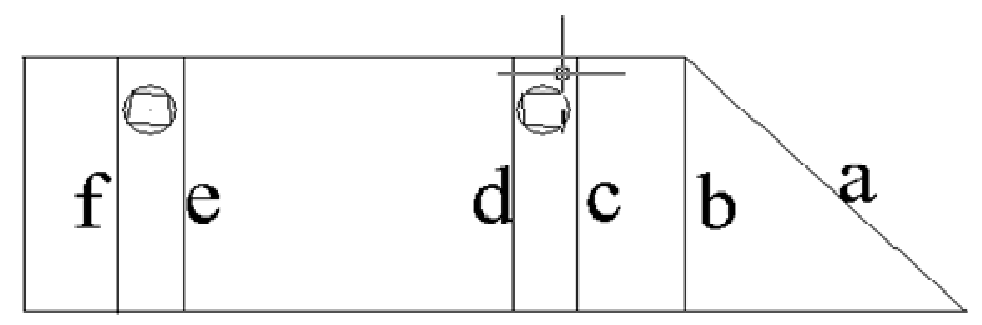

Fig. 4: Ploughshare showing the positions of dimensional losses

Table 3: Chemical composition of the ploughshare

\begin{tabular}{cccccccc}
\hline Element & $\mathbf{C}$ & $\mathbf{M n}$ & $\mathbf{N i}$ & $\mathbf{C r}$ & $\mathbf{S i}$ & $\mathbf{S}$ & $\mathbf{P}$ \\
\hline$\%$ & $0.4-0.5$ & $0.6-0.7$ & $0.2-0.3$ & $0.1-0.2$ & $1.3-1.6$ & 0.12 & 0.05 \\
\hline
\end{tabular}

Source: Bobobee et al, 2007 
Testing the abrasive wear of tillage tools...

63

(57-68.92\%). Comparing the wear to the the percentage of sand in the soil, the Akatsi soil recorded the highest average value of wear that could be due to its high sand content with the KNUST soil recording the least wear.

The KNUST soil that was classified as sandy clay loam and used in the experiment had a comparatively equal sand content to the Wenchi and Mampong soils, but its low wear rate could be due to its higher clay fraction in the $20-40 \mathrm{~cm}$ horizon.

The general finding of the study shows that wear increases with increasing sand content, which is in agreement with the results of Bobobee et al. (2007); Natsis et al. (1999); Ferguson et al. (1998) and Yu and Bhole (1990). According to Owsiak (1999), wear in sandy soil is $40-100 \%$ more than wear in clay soil. Again according to Scheffler and Allen (1988), wear was found to be twenty times higher in stony soils than in sandy soil and seven times greater than in clay soil.

From Table 4, analysis of variance showed significant differences $(p<0.05)$ exist in the weight loss among the five soils.

Fig. 6 shows the dimensional wear at the six

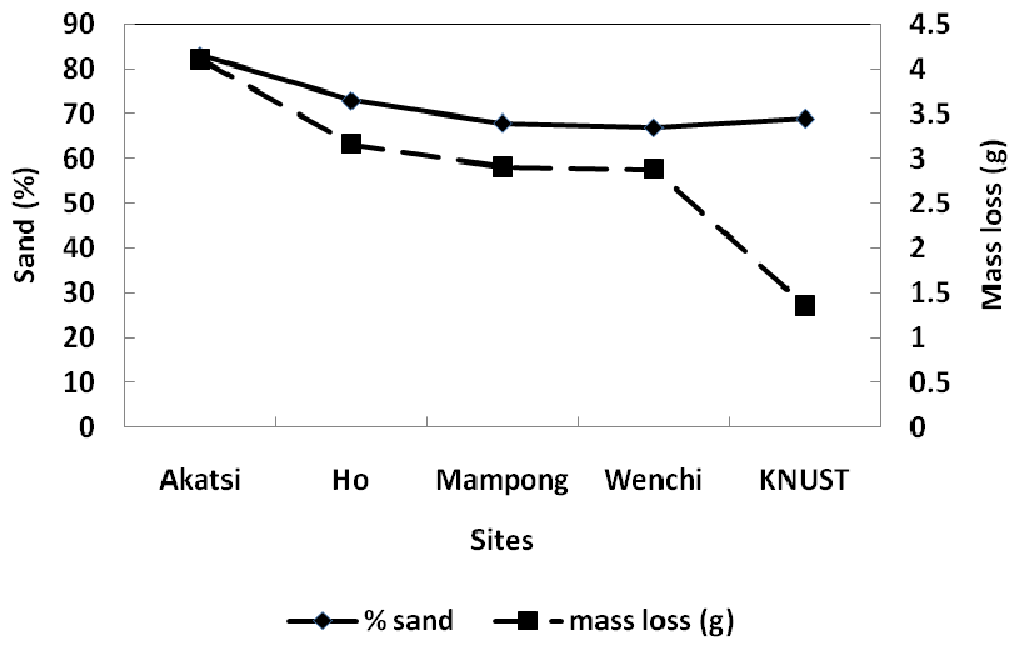

Fig. 5: Effect of sand content on weight loss of ploughshare in the five soils

Table 4: One-way ANOVA for wear of ploughshare in Ho, Akatsi, Mampong, Wenchi, KNUST

\begin{tabular}{lcrcrc}
\hline Source & DF & SS & MS & F & P \\
\hline Factor & 4 & 11.703 & 2.926 & 3.749 & 0.041 \\
Error & 10 & 7.803 & 0.780 & & \\
Total & 14 & 19.506 & & & \\
\hline
\end{tabular}


different positions on the ploughshare marked as $a, b, c, d, e, f$. The points $a, b, c, d, e$ and $f$ could be named as shin, leading face, front, middle, back and tail respectively. The shin (point ' $a$ '), experienced the greatest wear in all the five soils. The Akatsi soil recorded the greatest shin wear followed by Ho, Mampong, Wenchi and KNUST soils. This correlates with weight losses recorded in Fig. 5 above. The wear in Akatsi soil was highest at most marked places except at points ' $e$ 'and ' $f$ '. The wear in Ho soil followed after Akatsi soil at points ' $a$ ' and ' $b$ ' but dropped at points ' $c$ ' and ' $d$ '. It however recorded the highest values at points ' $e$ ' and ' $f$ '. It was also found that the ploughshare wear more at the bottom than any part. This could be the result of the compaction of the soil in the circular soil bin, which tends to increase with depth. The findings of this study indicate that there is a high correlation between weight loss and dimensional loss of the caststeel ploughshare in all the five soils. The result however disagrees with the findings of Graff et. al. (2007), who reported that mass change does not lead to the same conclusions as the dimensional change.

Influence of moisture content on wear rate of the ploughshare

From Fig. 7, the wear rate of the ploughshare was different for soils from each site. From Table 1, the Akatsi and Ho soils have higher sand fractions. The wear in these two soils increased with increase in moisture content. This is because as the moisture content increases, the packing density increases, which influences the shear strength of the soil. This is in agreement with the findings of $\mathrm{Yu}$ and Bhole (1990) and Natsis et al. (1999. This may be as a result of high sand content in the Akatsi soil. It is generally agreed that wear rate increases with increasing sand, gravel and stone content (Bobobee et al., 2007; Natsis et al., 1999; Ferguson et al., 1998; Yu and Bhole 1990). This was confirmed in this study. According to Owsiak (1999), wear in sandy soil is 40-100\% more than wear in clay. The ploughshare was found to wear most rapidly from the bottom with the leading edge (labelled $\boldsymbol{a}$ ) recording the highest loss of material and hence shape. The dimensional losses also gave the highest trend for Akatsi soil and the least for KNUST soil. The study shows high correlation exists between mass loss and dimensional loss of ploughshares.

Soils from Mampong and Wenchi also showed similar polynomial patterns in their wear rates with increasing moisture contents. The wear rate decreases with increasing moisture content up to a point (13\% for Wenchi and $15.5 \%$ for

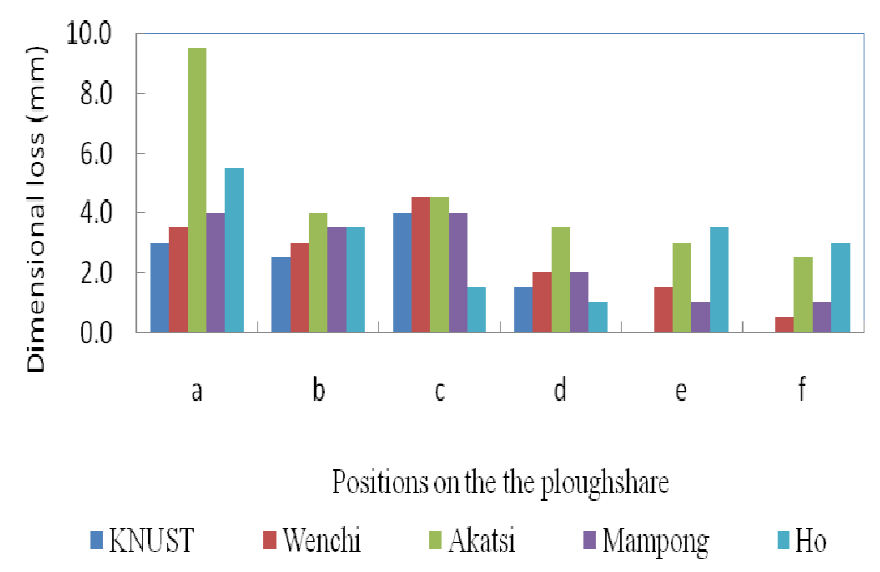

Fig. 6: Dimensional loss of ploughshare at the various marked positions 
Mampong), after which the wear rate increases with increasing moisture content. From Table 1 , soils from these sites have high percentage of clay fractions. According to Spoor (1979), at low moisture content, there is strong bonding between the clay particles causing them to be sticky. This tendency could cause the reduction in the wear of the ploughshare. However beyond $13 \%$ moisture content (for Wenchi) and $15.5 \%$ for Mampong), the trend reverses with an increase in wear against its corresponding moisture content. This is in agreement with the findings of Ferguson et al, (1998) and Natsis et al, (1999). Soil from KNUST, which has a mixed texture of sandy loam $(0-20 \mathrm{~cm}$ depth) and sandy clay loam $(20-40 \mathrm{~cm}$ depth) showed a polynomial trend of decreasing wear with increasing moisture content up to $10 \%$ before the wear increased slowly with increasing moisture content.

\section{CONCLUSIONS}

The circular soil bin as abrasive wear equipment has been developed for soil-tillage tool interaction studies. The design is such that it can be employed to test the wear of any soilengaging implements in different soils. This is a useful laboratory equipment for carrying out basic and applied research in tribology in the
Polytechnics, research institutes and industries in Ghana. The wear rate of the ploughshare is dependent on the soil type and its sand fractions. From the study, Akatsi soil with the highest sand content developed the highest wear rate followed by Ho, Mampong and Wenchi and KNUST, which recorded the least wear. The higher the sand content, the higher the wear rate of the cast-steel ploughshare. There was a high correlation between weight loss $(\mathrm{g})$ and dimensional loss $(\mathrm{mm})$ of the cast-steel ploughshare. In sandy loam and loamy sand soils, the wear of the ploughshare increased as the soil moisture content increased. On the contrary, in sandy clay loam the wear decreased with increasing moisture content up to a point before the trend reversed.

\section{SUGGESTIONS FOR FURTHER WORK}

It is recommended that further studies be carried out to develop the soil bin equipment to operate more than one tillage tools simultaneously. Also soils from other locations in Ghana should be tested for their abrasive wear characteristics.

\section{ACKNOWLEDGEMENTS}

Financial support provided by KNUST Research and Conference Committee for this pro-

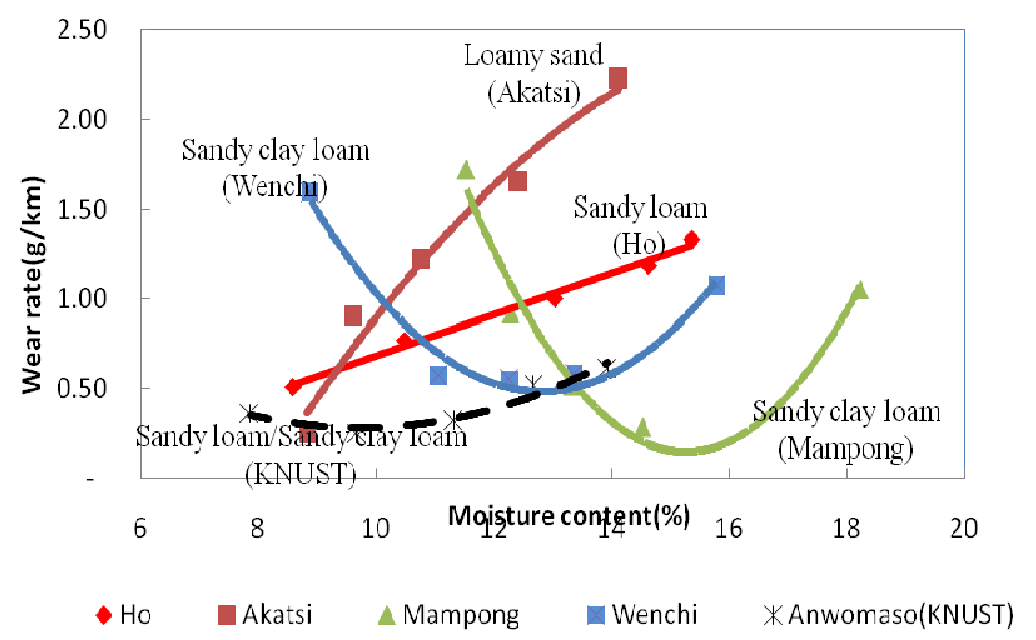

Fig. 7: Relationship between wear rate and moisture content 
-ject is duly acknowledged. Special thanks go to the University of Cape Coast for sponsoring Mr Kumi to pursue an MSc in Agricultural Machinery Engineering at KNUST. The authors also thank the technicians at the KNUST Agricultural Engineering Department workshop for the assistance in the construction of the first prototype. The authors thank the anonymous reviewers for their useful suggestions.

\section{REFERENCES}

Allen, C. and Ball, A. (1996). A review of the performance of engineering materials under prevalent tribological and wear situations in South African industries, Tribology International, 29: 105-116

Al-Janobi, A. A. and Eldin, A .M. (1997). Development of a Soil-Bin Test Facility for Soil -Tillage Tool Interaction Studies, Research Bulletin, 72: 5-26

ASTM (1991). Standard D2216-90. Method for laboratory determination of water (moisture) content of soil, rock, and soil-aggregate mixtures. In Annual Book of ASTM Standard 04.08: 278-281. Pheladelphia, P.A: American Society for Testing and Materials

Bayhan, Y. (2006). Reduction of wear via hardfacing of chisel ploughshare, Tribology International 39 (6): 570-574.

Bobobee, E. Y. H., Sraku-Lartey, K., Fialor, S., C., Canacoo, E. A, Agodzo, S. K, Yawson, A., and Gebresenbet, G. ( 2007). Wear rate of animal drawn ploughshares in selected Ghanaian soils, Soil and Tillage Research, 93: 299-308

Bobobee, E. Y. H., (1999). Animal traction utilisation, constraints and research options in Ghana. In: Renard, G., Krieg, S., Lawrence, P., von Oppen, M. (Eds.), Farmers and Scientists in a changing Environment: Assessing Research in West Africa. Margraf Verlag, Weikersheim, Germany, pp. 461-469
Chattopadhyay, R. (2001). Surface Wear: Analysis, Treatment and Prevention. ASM International Material Park, Ohio

Ferguson, S. A., Fielke, J. M., and Riley, T.W. (1998). Wear of cultivator shares in abrasive south Australian soils. Journal of Agricultural Engineering Research, 69: 99-105.

Graff, L. J., Roberge, R. C., Crowe, T. G. and Roberge, M. A. (2007). Wear of ripper point hardsurfacings. In Proceedings of the 2007 North Central Intersectional Conference of the ASABE, October 12-13, 2007, RRV07120. Fargo, ND: American Society of Agricultural and Biological Engineers.

Gurrumoorthy, K., Kamaraj, M., Prasad Rao, K. and Venugopal, S. (2007). Development and use of combined wear testing equipment for evaluating galling and high stress sliding wear behaviour, Material and Design, 28:98108.

Horvat, Z., Filipovic, D., Kosutic, S. and Emert, R. (2008). Reduction of mouldboard ploughshare wear by a combination technique of hardfacing, Tribology International, 41:778-782.

Khurm, R. S. and Gupta, J. K. (2003). A textbook of Machine Design. Eurasia Publishing House (pvt) Ltd. New Delhi

Manuwa, S. I., Ademosun, O. C., Agbetoye, L. A. S., and Adesina, A. (2011). Aspects of the development of outdoor soil bin facility (at FUTA) for soil tillage dynamics research. Proceedings of the Nigerian Conference on Tillage for Agricultural Productivity and Environmental Sustainability. Ilorin, Nigeria. (Feb. 21-23, 2011).

Mehulic, K., Schauperl, Z., Cvrljak-Tomic, I. and Badel, T. (2005). A method for Testing Abrasive Wear of Aesthetic Prosthetic Materials, Acta Stomatol Croat, 39 (2):177-180. 
Testing the abrasive wear of tillage tools ...

Ministry of Food and Agriculture (MOFA) (2011). Agriculture in Ghana - Facts and Figures.

MINITAB Inc. (2007). MINITAB Statistical Software Release 15 for Windows. Minitab Inc. State College, Pennsylvania

Natsis, A., Papadakis, G. and Pitsilis, J. (1999). The influence of soil type, soil water and share sharpness of a mouldboard plough on energy consumption, rate of work and tillage quality. Journal of Agricultural Engineering Research, 72: 171-176

Owsiak, Z. (1997). Wear of symmetrical wedge -shaped tillage tools. Soil and Tillage Research, 43(3-4):295-308.

Quirke, S., Scheffler, O. and Allen, C. (1988). An evaluation of the wear behaviour of metallic materials subjected to soil abrasion, Soil and Tillage Research, 11 (1): 27-42

Scheffler, O., Allen, C. (1988). The Abrasive wear of steels in South African soils. Tribology International 21(3): 127 -135

Spoor, G., (1979). Soil type and workability. In: Jarvis, M. G., Mackney, D. (Eds.), Soil Survey Applications Soil Survey, Technical Monograph No. 13. Harpenden, UK, pp. 7182

Tugrul, K. M and Icoz, E. (2005). Determination of Wear Characteristics of Drill Cultures of Precision Drilling Machine Made of Different Materials, Tarim Bilimleri Dergisi,11 (4): 428-433.

Tylczak J. H, Hawk, J. A. and Wilson, R. D. (1999). A comparison of laboratory abrasion and field wear results, Wear, 225-229 Part 2:1059-1069.

Yu, H. J., Bhole, S. D. (1990). Development of prototype abrasive wear tester for tillage tool materials. Tribology International 23 (5): 309-316 